\title{
Analysis of the results of structural ad- justment program on Algerian economy
}

\author{
Mekarssi Lemya, Yang kaijun \\ Business School, Hohai University, Nanjing 210098, P. R. China
}

\begin{abstract}
Before carrying out the structural adjustment program, the Algerian economy was struggling, characterized by dwindling foreign exchange reserves, rising foreign debt, dropping GDP growth rates, persistent budgetary deficits, high inflation, malaise the private sector areas of agriculture, construction and industry, rising unemployment, and supply and demand imbalances. To combat these fiscal and social problems, the fundamental pillars of the structural adjustment program were laid out in a May 1994 standby agreement. ${ }^{1}$

The fundamental objective of the structural reform program has been to restore growth, correct macroeconomic imbalances and improve economic efficiency. This paper tries to analyze the results of application of the structural adjustment program on overall economic balance. The findings of this study indicate that the results of the structural adjustment program at the level of the internal and external balances were mostly positive, but the positive results did not materialize without negative effects on the social side. This is not to say that structural adjustment program was wholly successful, as the amelioration in some economic indicators was actually due to favorable external factors (i.e. rising of oil prices in the international markets).
\end{abstract}

Key words: Algeria, structural adjustment program, results, overall economic balance.

\section{Introduction}

Facing a dire economic situation, Algeria, in cooperation with the World Bank and IMF, initiated far-reaching reforms in the form of a structural adjustment program in 1995. Before carrying out the structural adjustment program, the Algerian economy was struggling, characterized by dwindling foreign exchange reserves, rising foreign debt, dropping GDP growth rates, persistent budgetary deficits, high inflation, malaise the private sector areas of agriculture, construction and industry, rising unemployment, and supply and demand imbalances. To combat these fiscal and social problems, the fundamental pillars of the structural adjustment program were laid out in a May 1994 standby agreement, which was followed by an extended fund facility accompanied by the rescheduling of Algeria's foreign debts over three years. ${ }^{1}$

With the implementation of the 1994 reform program, Algeria marked a solid departure from the past, in terms of both macroeconomics policy and results. The program was put in place following a severe external payments crisis, in the wake of the oil price drop throughout 1993. The Government introduced swift stabilization and adjustment measures, including a strong fiscal adjustment; tight monetary policy; an active exchange rate policy; and price liberalization. The program was accompanied by a debt rescheduling agreement with the Paris and London clubs, and the initiation of structural reforms, including privatization. ${ }^{2}$ 
The main objectives of this program are to restore the economic growth, correct macro-economic imbalances by lowering budget deficit and external debt, adjust the exchange rate, rebalance the balance of payment and contain inflation, ect. It more appropriate to give some answers to the following question: What are the results of the application of the structural adjustment program on the overall balance of Algerian economy?

\section{Analysis of the results of structural adjustment program on Algeria's economy:}

\subsection{GDP growth:}

The reform program succeeded in reversing the long past decline in GDP growth, but the recovery is still slow and subject to large fluctuations provoked by weather and oil price variability ( see figure 1$)^{2}$

The GDP growth in 1995-1996 averaged $3.95 \%$, due to the raise of oil prices in the international markets and to the good climatic conditions that permitted to ameliorate the agriculture productivity that led to increase the rate of contribution of agricultural sector to the GDP from 15\% in 1995 to $21.5 \%$ in 1996 . Also the amelioration in the volume of imports by $2 \%$ and that had a positive impact on the household consumption that increased to $2.5 \%$ and increase of investments to $3 \%$ in 1995 against $0.2 \%$ and $0.5 \%$ respectively in 1994.

However, the increase registered in the GDP declined again in 1997 by $1.1 \%$ because of the deterioration in the agricultural sector, as well as lower growth in the construction sector and public works and a continued decline in the industrial sector level. Economic performance in 1998, with a GDP growth rate of $5.1 \%$, was exceptionally high despite the oil price shock, principally due to an exceptionally good harvesting year by good rainfalls, and some recovery in manufacturing resulting from the restructuring efforts of the previous 4 years.

In 1999, GDP growth dropped again to $3.2 \%$, mainly due to a substantial slowdown of the non-hydrocarbon sector, due to the budgetary impact of the sharp drop in oil prices. This was due to the deceleration of the construction and services sectors, compounded by a severe slowdown in agriculture due to an important late-season drought that mostly affected the cereal sector.

From 2000 to 2011, the country's GDP growth rate averaged $3.5 \%$, It reached only $2.5 \%$ in 2011 as a result of the structural decline in oil production.

The contribution made by hydrocarbons to GDP dropped from $48.4 \%$ in 2006 to $37.0 \%$ in 2011. The effect of this fall on oil revenues was mitigated by the good performance of the price of oil which averaged USD 112.8 per barrel in 2011. The hydrocarbons sector remains the engine of the nation's economy: by itself it produces $70 \%$ of budgetary receipts, making possible a sustained high level of public spending. ${ }^{3}$

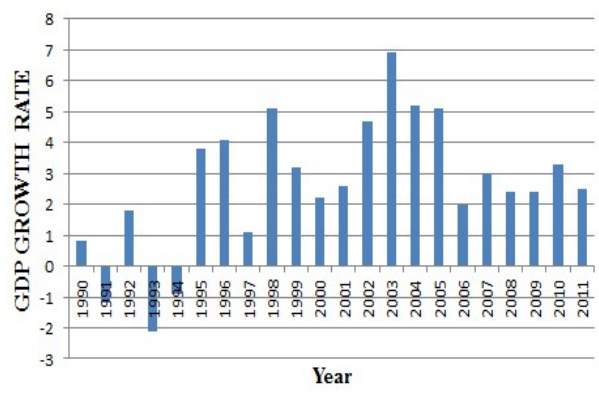

Fig. 1: GDP growth rate (in percent) (Source: World Bank data)

\subsection{Inflation:}

Inflation remained under control, mainly due to the prudent monetary policy pursued by the Bank of Algeria ${ }^{4}$ (see figure2). 


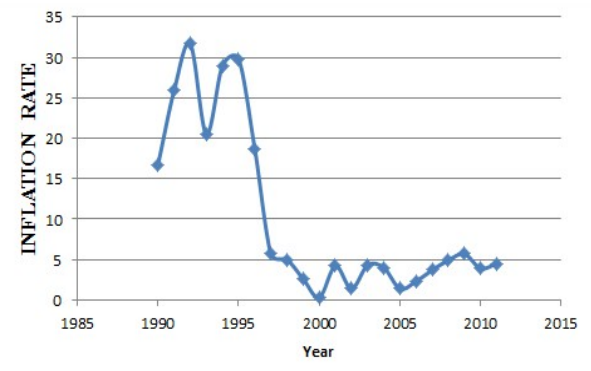

Fig. 2: Inflation Rate (in percent) (Source: World Bank data).

The period that preceded the structural adjustment program was distinguished by high rates of inflation, where the rate reached $31.7 \%$ in 1992 . between 19951996 the inflation rate declined by $3.7 \%$ due to the execution of the structural adjustment program, where the inflation rate decrease from $29.8 \%$ in 1995 to 18.7 $\%$ in 1996 . After this, the inflation rate continued to decrease to reach about $0.3 \%$ in 2000 and this is the lowest inflation rate known by Algeria since its independence, and this is due to the restrictive procedures and policies adopted by the successive governments within the scope of the structural adjustment program as devaluation of the Algerian dinar, prices liberalization, wages control, reducing the deficit of the budget, control the money supply and following new methods to finance economic activities.

However, in the beginning of 2001 the inflation rate rose again to reach about $4.2 \%$ this is due to the increase of money supply which its growth rate reached $24.9 \%$ in the same year because of the economic revival program. During the period 2002-2010, inflation was around $3.5 \%$ annually, as a result of the pressure exerted by rising food prices, the rate reached $4.9 \%$ in 2008, 5.7\% in 2009 and $3.9 \%$ in 2010.

Inflation got worse, with a rate of $4.5 \%$ in 2011 , as against $3.9 \%$ in 2010 , as a con- sequence of rises in food prices, which increased from $3.64 \%$ in 2010 to $4.22 \%$ in 2011. The higher inflation figure is also due to the high cost of imported goods and a rise in the prices of health and physical-hygiene products. The average price of manufactured goods rose by $5.5 \%$ in 2011 . The increase in the costs of services was $3.3 \%$. The rises in the prices of staple products such as cereals, milk and sugar would have been greater still in 2011 if they had not been subsidized. In respect of gas and electricity, the government continues to spend USD 7 billion to cover the gap between the cost price and the amount charged to the consumer by Sonelgaz on the domestic market. Drinking water enjoys similar treatment. ${ }^{3}$

\subsection{Balance of payments:}

From 1990 till 1994, the balance of payments registered an unstable results, where recorded a small surplus about 0.5 billion dollars in 1991. The balance of payments reached the biggest deficit in between 1994 and 1995 which are years of the intense crisis in the foreign payments that Algeria faced, the deficit reached about 6.32 billion dollars in 1995 and this is due to the fall of oil prices and the increase of foreign debt services, But in the end of 1996 and the beginning of 1997 the results of reforms applied in the foreign sector showed by the positive balance of the balance of payments that recorded a surplus of about 1.16 billion dollars in 1997 resulting principally from the positive balance of trade balance, then the balance of payments recorded in 1998 and 1999 a deficit of 1.74 and 2.38 billion dollars respectively as a result of reduction of exports revenues due to the decrease of oil prices.

From the beginning of 2000 till 2008, the balance of payments recorded a surplus, that reached in 2008 around 37 billion dollars and which is the highest surplus ever realized by the balance of payments 
in Algeria since the independence, the reason of realizing this increase is due to the rise of the oil exports. In 2009, the balance of payment balance dropped to 3.9 billion dollar, mainly due to the fall in the value of oil exports $(-42.5 \%$ in 2009 , compared to 2008) linked to the global economic crisis. The situation improved considerably in 2010 and 2011 with a balance of payment surplus of 15.6 billion dollar and 20.1 billion dollars respectively as a result of the rising price of oil per barrel, enabling export earnings to reach 57.1 billion dollars in 2010 and 72.9 billion dollars in 2011, compared to 45.2 billion dollars in 2009. (see figure 3)

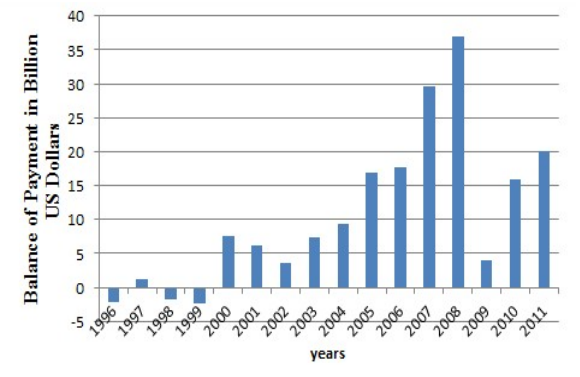

Fig. 3: Balance of payment in billion US dollars (Source: IMF country reports).

\subsection{External debt:}

The external debt of Algeria recorded high rates during the nineties, despite the reforms undertaken by Algeria. The Algerian external debt of achieved its maximal rate in 1996 with around 33.42 billion dollars. Then the external debt was brought down from 30.66 billion dollars in 1998 to 4.41 billion dollars in 2011 which is the smallest value recorded during 1990-2011. This fall in the foreign debts indicator resulted from the rise of the foreign capital flows due to the increase in oil prices besides the relative stability of the Algerian economy during the last years and that reduced the rate of foreign loans.
In general, this progress recorded at the level of foreign debts during the last years doesn't really mean a permanent improvement given that the situation in Algeria is subordinate to the oil prices fluctuation.

\subsection{Budget balance:}

From the beginning of 1996 till the end of 1997, the budget balance registered a surplus due to the heavy pressure practiced on equipping expenses and the increase of tax incomes (the oil tax revenues). However, the fall in the oil price during 1998 led to the drop of oil tax which represents usually $50 \%$ of the total budget revenues, despite of this regression, it still represents more than $48 \%$ of that total and that had a negative impact on the budget balance that registered a negative balance of 101.2 billion DA.

The budgetary position, which was in surplus from 2000 to 2008 (13.5\% of GDP in 2006, $4.4 \%$ in $2007,7.7 \%$ in 2008), recorded in 2009 and 2010 deficits reaching $6.4 \%$ and $2.4 \%$ of GDP, due to the combined effect of lower oil revenue and high levels of public expenditure following the implementation of an ambitious public investment program. The deficits of 2009 and 2010 were funded in part by the Revenue Regulation Fund (FRR) set up in 2000 to insure public spending against fluctuations in oil production and prices. ${ }^{3}$ In 2011 the budget deficit reached $3 \%$ of gross domestic product (GDP). ${ }^{3}$

It is obvious from what it precedes that the Algerian economy is characterized by a chronic deficit in the state overall balance which is considered as one of the main factors of disequilibrium that occurred in the internal financial balance. The reasons of the persistence of the deficit can be summarized in the increase of public expenditures with an average higher than the increase of total incomes, that's why, this situation shows that the 
budget is still in dependency to oil markets situation ,the same situation as before, and which is contrary to reforms goals that's why it is necessary to reconsider the tax structure and to fight tax avoidance and fraud ; it is also necessary to rethink the management expenses ( especially wages) and capital expenditure financing the government investments and which represent the base of the economy.

\subsection{Exchange rate:}

One of the immediate objectives of the program was to correct the previous real appreciation of the Algerian dinar Along with broad trade liberalization measures, including on trade-related payments, a two step devaluation of the Algerian dinar (in total 70 percent) took place between April and September 1994. ${ }^{5}$

Since 1995, Algeria's exchange rate policy has aimed at maintaining a stable real exchange rate against a basket of currencies weighted according to the country's main trading partners and competitors. In 1995, the managed float regime was implemented through fixing sessions between the Bank of Algeria and commercial banks. An interbank foreign exchange market was established in $1996 .^{5}$ Between 1995 and 2002, the exchange rate appreciated by $67.08 \%$ that means the domestic currency depreciated by $67.08 \%$ in average against the dollars, followed by a depreciation of $2.91 \%$ in average between 2003 and 2004, which means the Algerian dinar appreciated by 6.84\% against dollars. From 2006 to 2008 the Algerian dinar appreciated by around $11 \%$ against the dollars, due the increasing in the oil revenues, and increasing in the foreign currency reserves, also due the depreciation of the dollars because of the financial crisis in 2008. Between 2009 and 2010 the exchange rate appreciated, where recorded 72.6 dinars per dollar and 74.4 dinars per dollar, respective- ly. In 2011 the Algerian dinar appreciates again by 72.9 against the dollars.

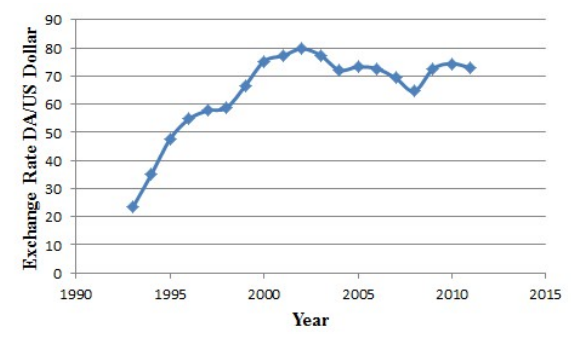

Fig. 4: Exchange Rate DA/US dollar (Source: IMF country report)

\subsection{Unemployment:}

Despite the fact that amongst the main targets of the reform program in Algeria is to reduce the unemployment rates except that the results were negative because of the interruption of investments in the public sector. The unemployment phenomenon knew a continuous increase during the years of the reform program because of the Layoffs due to the procedures of restructuration and dissolution of public enterprises on one hand and the rise of the demographic growth rates during the Nineties on the other hand, and that led to the worsening of the social conditions.

During the period 1994-1999, the unemployment rate increased by $23.11 \%$, where in 1999 reached to $29.99 \%$ which is the highest unemployment rate recorded during 1990-2010

In recent years, the unemployment rate has dipped from nearly $29.77 \%$ in 2000 to $10 \%$ in 2011 , but it remained high among youths under 30 years.

To address this matter, the Government has established a key mechanism for providing counseling and support to unemployed youths (establishment of the National Youth Employment Support Agency and mechanisms to facilitate professional integration). However, the results of these initiatives are still mixed. 
The Government is also focusing on diversifying the sources of growth and developing the private sector as likely areas of job creation. In addition, efforts are underway to alleviate the housing problem. More than one million housing units were built between 2004 and 2010, which helped to raise the housing stock to $7,090,000$. Even so, this is still short of the needs, considering the rapid urbanization that the country has experienced over the past 30 years. ${ }^{4}$

\section{Conclusion:}

In summary, conclude that many aspects of the structural adjustment program had great success and revitalized Algeria's economy. On the macroeconomic level, some indicators showed a return to more economically acceptable levels. ${ }^{1}$

After the program's completion, growth rates registered a positive growth rate, but this growth still not enough and fragile, because it is depend on hydrocarbons and agriculture sectors. Unemployment is dropping but still high. The structural adjustment also contributed to lowering foreign debt and debt servicing rates.

In addition, the dinar's exchange rate was relatively stable against major currencies and the gap between the official rate and the parallel market's rate dwindled, inflation fell from $29.78 \%$ to $3.91 \%$ in 2010, and the real interest rate became positive.

The budget balance was characterized by a chronic deficit which is considered as one of the main factors of disequilibrium in the internal financial equilibrium, the reasons of the persistence of the deficit can be summarized in the increase of public expenditures with a rate higher than the increase in of total revenues, that's why, this situation shows that the budget is still in dependency to oil markets situation, the same situation as be- fore, and which is contrary to reforms goals.

Conclude from all of the above analysis that the results of the structural adjustment program at the level of the internal and external balances were mostly positive, but the positive results did not materialize without negative effects on the social side.

Finally, this is not to say that structural adjustment was wholly successful, as the amelioration in some economic indicators was actually due to favorable external factors (i.e. rising of oil prices in the international markets).

\section{References:}

[1] Mohamed Ratoul 2008, Economic Reform and Political Openings: lessons from Algeria, Emerging Financial\& Economic Trends.

[2] Mohamed Abdelbasset Chemingui 2003, What Macroeconomic Factors Explain Algeria's Poor Economic Growth Performance?, Journal of Economy Planning (forthcoming (2003).

[3] African Economic Outlook 2012, Algeria's report, www.africaneconomicoutlook.org

[4] African Development Bank Group (Algeria) 2011, Dialogue note 20112012.

[5] Taline Koranchelian 2005, The Equilibruim Real Exchange Rate in a Commodity Exporting Country Algeria's Experience, IMF Working Paper WP/05/135.

[6] Bank D’Algérie, Bulletin Statistique trimestriel $\mathrm{N}^{\circ} 18$ (Juin 2012), web page : http://www.bank-ofalgeria.dz/bulletin_statistique.htm

[7] IMF (2001), “Algeria: Statistical Appendix”, IMF country report No. 01/163, Washington 
[8] IMF (2006), “Algeria: Statistical Appendix", IMF country report No. 01/163, Washington

[9] IMF (2009), “Algeria: Statistical Appendix", IMF country report No. 09/111, Washington

[10] IMF (2012), “Algeria: Statistical Appendix", IMF country report No. 06/102, Washington
[11] IMF (2012), “Algeria: Statistical Appendix", IMF country report No. 06/102, Washington

[12] O.N.S, national office of statistics: Algeria, www.onz.dz/index-en.php

[13] World Bank 2013, World Bank Group Official web page.www.worldbank.org/indicator 